\title{
Sadrettin Celal Antel's Ten-year Ministry Development Report: An Assessment Based on the Divisions of Educational Sciences
}

\author{
Savas Karagoz \\ Department of Educational Sciences, Faculty of Education, Aksaray University, Aksaray, Turkey
}

Copyright $\subseteq 2018$ by authors, all rights reserved. Authors agree that this article remains permanently open access under the terms of the Creative Commons Attribution License 4.0 International License

\begin{abstract}
Except other reasons such as politics, economics and military, the decline and collapse of the Ottoman Empire are because of outdated education system. After the proclamation of the Republic, the newly established Republic of Turkey gave great importance in education with its all dimensions to not fall into that error Ottoman Empire had fallen. Many educators who grew up during the 2nd Constitutional Monarchy and took part in the formation of the Republican period education presented and revealed their opinions and suggestions on education. What is interesting in their thoughts is that they are now being implemented as an education policy in modern Turkish education system. In this qualitative study, the report written in 1926 by Sadrettin Celal Antel and published in the Journal of Turkish Education Ministry, titled as "Ten Years Improvement Report", was first transcribed to today's Turkish and then compared to the recent regulation issued on June 16th, 2016 by Turkish Higher Education Council of educational sciences as study disciplines. The study of education in Turkey was divided into the subfields of Philosophical, Social and Historical Foundations of Education, Education Curriculum and Instruction, Education Management, Lifelong Learning and Adult Education, Teaching Technologies and Guidance and Psychological Counseling. The comparison has revealed that educational sciences not only achieved the aims of the main sciences but also included opinions and suggestions compatible with today's contemporary pedagogical understanding.
\end{abstract}

Keywords Educational Sciences, History of Education, Sadrettin Celal Antel, Pedagogical Reforms, Development of Pedagogy in Turkey

\section{Introduction}

Educational sciences study its own issues and problems through scientific (epistemology, ontology and axiology) theories. The educational sciences are also defined as a science that relates and integrates the social, economic and political phenomena of scientific theories with its own terminology and methodology $[1,2,3]$.

Since the 19th century, many developments have taken place in the field of industrialization, which depends on the humanistic and realist idea. Related to these developments, philosophical thinking and developments in sociology and psychology have increased the need for educated and productive people. These needs have directly influenced the educational structure of the countries and have led the education to regulate or renew according to the necessities of the time.

The words "Education" and "Science" were first used in Alexander Bain's famous work "Education Science (La Scence de L'Education)" in 1879. In the late nineteenth century, changes and development in educational sciences moved from philosophical and logical understanding of German educators to the scholastic-empirical understanding of the Anglo-Saxon educators [4].

In 1910, Lucien Cellerier took educational sciences a step forward with his famous work "Pedagogical Science Draft (Esquise d'une Science Pedagoque)". The concept of educational intelligence has taken the form of "educational sciences" through the Institute of Educational Sciences, founded in 1912 by the psychologist E. Claparade. After these dates, educational sciences have gained the identity of a disciplinary community composed of many scientific disciplines and subdivisions belonging to these sciences [3].

Turkey's modernism progress starting by the republic affected the education system and in this process the integrity between the foundation philosophy of state and basic philosophy of education system provided positive improvements in education [5].

When considering the development of educational sciences in Turkey, the foundation of educational sciences was laid by the foundation of the school that trained male 
teachers in March 16, 1848 after the proclamation of the Tanzimat (the political reforms made in the Ottoman State in 1839), with altering the educational structure according to the western sense [6]. Educational sciences in Turkish education system were basically developed by some educators such as İsmail Hakkı Tonguç, Ali Haydar Taner, Nafi Atuf Kansu, İbrahim Alaadin Gövsa, Mustafa Rahmi Balaban, Hıfzırrahman Raşit Öymen and Sadrettin Celal Antel $^{1}$ and their works after the second constitutionalist period [7]. İsmail Baltacıoğlu's works, "Revolution in Education" and "Educational Science", are among the valuable works in terms of educational sciences [8].

The final version of the educational sciences in Turkey was reorganized with the consideration of the existing sections and departments of the Faculty of Education and Educational Sciences at the Higher Education Council $(\mathrm{YÖK})^{2}$ meeting in 15.06.2016. By this arrangement, educational sciences were divided into 7 departments;

1. Department of Philosophical, Social and Historical Basis of Education

2. Department of Assessment and Evaluation in Education

3. Department of Curriculum and Instruction

4. Department of Educational Administration

5. Department of Lifelong Learning and Adult Education

6. Department of Educational Technology

7. Department of Psychological Counseling and Guidance

The disciplinary areas in YOK's new regulation of educational sciences in 2016were placed in the report presented to the Ministry of Education by Sadrettin Celal Antel in the subheading "10 years of Development Program for Our Education" under the title of "A Brief About the Ministry of Education", which was published in the 7th edition of the Ministry of Education Magazine consisting of 112 pages [9]. When this report is analyzed, it shows similarities with the Mialeret's parts of educational sciences, educational history, educational

\footnotetext{
${ }^{1}$ Sadrettin Celal [Antel] was born in Istanbul in 1890. He did his primary education at home with lessons from private teachers. In 1908, He completed Numune-i Terakki High-School and entered law school in the same year. He was sent to France in 1909 to take the foreign examination of the state. He studied at the Lycée Louis-le-Grand in Paris in 1909-1910, and at the Ecole normale d'Auteuil in 1910-1911. Sadrettin Celal Antel also took Emile Durkheim's educational lessons in Sorbonne [10]. Sadrettin Celal Antel, who returned to Turkey in 1913, was appointed as Director of Adana Darülümüallimin (Adana Male teacher school) and Teacher of education courses. Sadrettin Celal Antel was a high school teacher. He was appointed a professor of Education at Istanbul University Faculty on 29.12.1936. In the years of World War II, he wrote foreign policy articles under the name of "antenna" in the "tan" newspaper. Therefore, he was taken from the position of the Ministry of national education. Antel, who returned with the decision of the Council of state, died on February 12, 1995 in his office of the Faculty as a result of "standing in the heart" Ülken $[11,12,13,14]$.

2 The Council of Higher Education (YÖK) was established with the Law No. 2547 dated 6 November 1981. With this law, it has commenced in a restructuring process of academic, institutional and administrative aspects in higher education.
}

sociology, educational ethnology, school statistics, educational economics, school management and comparative education and the study of the restructuring of educational sciences dated 2016 by YÖK. "10 years of Development Program for Our Education" is consisting of 10 headings: Change our minds about school and education, School system, Pedagogical innovations to be made in schools, Social training, Teacher training, Ministry of National Education and Provincial Organization, Benefit from knowledge and developments in the western world, Education museum and Institute of Higher Education

\section{Aims of Research}

The aim of this research is to reveal the "10-year Development Program for Our Education", which was written under the heading of Sadrettin Celâl Antel "A Brief About the Ministry of Education", is the basis of regulation on the educational sciences that the Higher Education Executive Board has determined at its meeting dated 15.06.2016. For this purpose, the answers to the following questions were searched:

1. What are the opinions and recommendations of Sadrettin Celal Antel about Department of Philosophical, Social and Historical Basis of Education?

2. What are the opinions and recommendations of Sadrettin Celâl Antel about Department of Measurement and Evaluation in Education?

3. What are the opinions and recommendations of Sadrettin Celal Antel about Department of Curriculum and Instruction?

4. What are the opinions and recommendations of Sadrettin Celâl Antel about Department of Curriculum and Instruction?

5. What are the opinions and recommendations of Sadrettin Celal Antel about Department of Educational Administration?

6. What are the opinions and recommendations of Sadrettin Celâl Antel about Department of Lifelong Learning and Adult Education?

7. What are the opinions and recommendations of Sadrettin Celal Antel about Department of Educational Technology?

8. What are the opinions and recommendations of Sadrettin Celâl Antel about Department of Psychological Counseling and Guidance?

\section{Method}

The research was based on qualitative research method. Qualitative research is a type of research based on induction method. It tries to describe phenomena and events through data collection tools such as observation, 
interview and document analysis in their natural environment and tries to reflect the perspective of the participants $[15,16,17]$. In this research, document analysis covers the analysis of written materials that contain information about the targeted cases. Document analysis analyze documents produced in a specific period of time about a research problem or documents produced at different intervals by more than one source on a related topic based on a wide time frame. Document analysis is an inevitable data collection technique for almost every research. The data was compared with the criteria of the reorganization of educational sciences and educational sciences faculties of YÖK in 2016 and the analysis of Sadrettin Celal Antel's "10-Year Development Program for Our Education". The report published under 10 headings was analyzed according to the objectives of the eight departments in the regulation that YÖK made for educational sciences.

\section{Findings}

\subsection{What are the Opinions and Recommendations of Sadrettin Celal Antel about Department of Philosophical, Social and Historical Basis of Education?}

Societies establish a relationship between the increase of education level and productivity and believe that the contribution people made to his society is proportional to the education they received. It is admitted that the quality level of educational activities has an influence on the quality of economic, social, political and cultural development of the society [18].

The report is examined in terms of philosophical, social and historical foundations of Education. The philosophy of Turkish education system was defined as "In order for a nation to be able to self-govern, citizens who constitute that nation must themselves be judges and be able to self-govern, and when necessary, be able to sacrifice their personal interests to their common and high interests in their own way."

It is emphasized that gaining new spirit, a new ideal and new moral values for young people have vital importance and the Government of Turkey is obliged to organize education by taking into account this basis in order to become people's government.

It has been proposed to make studies on shaping the education according to the existing social life to form a national consciousness and specifying patches that is taken from France education system, adding or subtracting some courses, changing the names of the schools because increasing only the numbers are not a real work. In this regard, the report has included changing our thinking about school and education and connecting schools with the social and economic life of the nation.
In terms of historical basis of education, it is focused on the necessity of changing schools and our educational habits of Middle Ages and importance of knowledge and reorganizing of education system according to necessities of society and the time "The method to be applied in education is "knowledge". Knowledge is not much of an ornament for man; it is not a vehicle or a marvelous pleasure to put pressure on someone else. Knowledge is the most effective way for individual to be successful in life".

As art is not for art, school is not for school. The school is for society. School must open its doors to life. The mark of school: The school must be with life for life. Revolution is urgently needed in our school system. Emphasizing that the educational issue is not just a pedagogical issue, education is multifaceted and especially socially important. It has been explained as:

"nor to change or renovate the educational methods, or to open or close five to ten schools or teacher training schools are not basic reasons. Bringing the most excellent teachers from Europe, adding some lessons to the programs etc., are real reasons to investigate if our aims are pedagogical matters."

The educational issue has been seen as a social issue and it has been suggested that the purpose of education should be to train people who raise the level of the nation to the level of civilization and increase the production of the country. School system inherited from Royalty and government of constitutional period is an aristocratic organization which does not categorize children according to their knowledge and ability. As a result, it leads to the waste of our most precious spiritual wealth. In the report, the main purpose of the educational reform due to the negligence of young people's social and moral development is to make schools give social and moral values to young people according to the needs of modern Republic of Turkey. It is expressed in the report as: There is a very natural relationship between the political and social system of a society and the education system. The main aim of Education and School is to educate people who will sustain the system and continue as it is.

The period has changed; the provincial government was replaced by the People's Republic. But unfortunately, in our schools, the constitutionality mentality mixed with the old empire spirit continues to dominate. The young people wanted by the People's Republic are people who are completely different in mentality and ability. It is necessary to launch a large republican air in the Schools.

Similarly, Dewey (1925) emphasized the importance of arousing political and social awareness in students in his report for Turkish educational system. Later, in 1997 Turkish education system employed new curriculums based on constructivism philosophy. With this new philosophy, democracy and being a part of democratic system are thought in schools [19]. 


\subsection{What Are the Opinions and Recommendations of Sadrettin Celâl Antel about Department of Measurement and Evaluation in Education?}

In the field of assessment and evaluation in education, Sadrettin Celal Antel has stated that the application of current exams has a negative effect on the psychological structures of children. In this regard; emphasizing the necessity of changing the examination system, he indicated that exams do not provide accurate information about children's intelligence, intellectual levels, true knowledge and their specific abilities.

It has been stated that the application of the school scoring system for evaluation is of great benefit in terms of knowledge of children and young people's intelligence, individual and special abilities, psychological characteristics, intelligence levels, health conditions and signs for both students and teachers.

It has been suggested that school scoring system is beneficial as students move from one classroom to another, from one place to another. It is appropriate to better understand the teacher's student, to better understand the type and degree of his intelligence.

Another important benefit of the scoring system in terms of assessment and evaluation is that it will facilitate the early diagnosis and treatment of many physical and psychological disorders. It is emphasized that the scoring system is also a system that can be used for career selection and guidance to the professions.

It has been emphasized that in that period, the various pedagogical tests carried out by our various schools have been used to determine and measure intelligence and abilities but these tests are insufficient to direct children to appropriate areas. It has been criticized that at the end of this assessment, children who are fit to grow up as skilled workers in practical areas but who do not have the intelligence to pursue a high education occupied moderate and high educational positions unnecessarily because of their good financial situation.

Likewise, measuring development of students with multiple choices examination cannot show the real progress of the students. So, performance -based evaluation should be added to education system [20].

\subsection{What Are the Opinions and Recommendations of Sadrettin Celal Antel about Department of Curriculum and Instruction?}

When the report is examined in terms of curriculum and instruction, he first sought answers to the question "How should the program be organized to develop the education?". This program should be regulated by an authorized scientific committee. Moreover, enough explanation has been made about how this scientific committee is formed. It has been criticized that when the reforms and programs in education are being made, only the professors, teachers and partly pedagogues are consulted and only their individual views are taken. The reason for the criticism is explained in the report with the following statements:

"The programs have been dealt with by these individuals just as a technical pedagogical matter. Teachers have advocated the rights of lessons in their area of specialization. They tried to allocate as much space as possible for these lessons in the programs. Pedagogues have been affected more or less by abandoned educational movements for centuries and have requested some modifications and reforms in our training and education procedures."

It was proposed that when the course programs were made, the subjects should be selected from environment and economic activities. It has been suggested that it is necessary to alleviate programs and to determine the degree of knowledge according to the child's level. It has been expressed that by emphasizing the importance of the relationship between the topics in the program, the most important program renewal in schools, especially in primary school is that it is necessary to establish the relationship among history, geography, account, examination nature, picture, hand work courses instead of separating courses.

Programs should also be made according to individual characteristics and taking into account the intelligence, ability, psychological and physical characteristics of the students. It is also important to combine the education and art in the program.

New training methods must be included in the program of applied schools. It has been stated that procedures produced by all famous pedagogues and applied successfully in the modern schools of Europe and America should be applied. It is also suggested that the programs should be prepared by taking the Dalton Plan, Declori, Couzine, John Dewey, and Ferreira methods into consideration and be applied especially in the applied schools depending on the teacher training schools [21].

\subsection{What Are the Opinions and Recommendations of Sadrettin Celal Antel about Department of Educational Administration?}

\section{Central and Provincial Organization of Ministry of Education}

The Ministry of Education is the guide and order of the ideological life of the country. The fact that the Tawhid-i Tedrisat (Unification of Education) issue has been partially resolved is a major development in this area. But recently there has been a regression with the influence of various managers.

Today, the various ministries have taken vocational training that is relevant to them. First of all, this duality should be removed. All the institutions (such as the 
theaters, the cinemas and school of music) that are related to college and education in the country should go under the control of the Ministry of Education together with all the schools.

The education system in the country is a whole. The Ministries of Education must obtain all their rights and become a great National Ministry of Education with all their means. Some changes are necessary in the central and provincial organization of the Ministry of Education. In order for the Ministry of Education to become a major national ministry of education in the desired manner, the central and provincial organizations are required to be organized according to the following principles.

Central Organization: Minister of Education is the political representative of the Grand National Assembly in the Ministry of Education. The Undersecretary is the minister's technical consultant. He is both a pedagogue and an administrative person and handles technical and administrative issues of the Ministry. Having a managerial and organizational ability with a great educational qualification is necessary for appropriate work.

It should be the duty of the undersecretary to approve or remove the administrative and scientific elements of the schools. In this respect, it is very necessary to know well and have a basic idea about teachers, principals, inspectors, and their supervisors. Frequently changing the Ministers of Education is not right. Also frequent changes of the undersecretaries are not right, too.

There is a need to create a scientific committee under the Ministry of Education: It is necessary to establish a scientific committee where the highest authority is the Minister of Education. The first task of this committee is to organize the education development program.

In addition, this scientific committee should make or change the programs of the schools, give directives about the curriculum and instruction to all the institutions of education and determine the types and grades of schools that are necessary to be opened.

There will be a permanent bureau that will work on a permanent basis, determining how and by whom the scientific committee under the Ministry of Education is formed. This permanent office member will work on specific issues according to their field of specialization, and will follow the educational events of the western world day by day. They will also have permanent contact with the great pedagogues of the world and important education organizations. They will identify those that are possible and necessary to be investigated and dealt with when necessary.

It is necessary to associate the inspection works according to scientific principles: One of the ministry's greatest duties is to arrange supervision works on a very firm basis, and to develop and complete the existing supervision committee. The issue of supervision should not be considered just as administrative like today. Inspectors in a backward country in education field like ours must raise the levels of the teachers and guide teachers to adapt them to teaching methods.

In addition to the administrative supervisors who are responsible for inspecting the work of the principals, sufficiency of the buildings, reporting students' attendance to school and reporting moral and physical activities of school to Ministry, guide supervisors are needed. The duty of this inspector is not only to see the flaws and deficiencies of school principals and teachers, but also to classify them and introduce them to modern teaching methods and get them applied. If the guidance supervisor considers it necessary, he must live for a few days in school, and follow the education.

After the first supervision, for example, in a school where an autocratic discipline is dominant, he must guide the director and teachers to apply the self-government system. He must work with them for days. The centers of the guide supervisors are the districts of education. However, the fact that these guide inspectors are not left alone is a necessity and there must be many assistant supervisors of women and men under the guide of the supervisor. These assistants will be both an assistant inspector and will also bring up under his supervision.

In the central organization of the Ministry of Education, officers and statistical offices should be located: It would be more useful to put civil officers and statistical bureaus instead of closing today's primary and secondary education directorates. Existing administrations are interfering with the scientific lives of the schools under their control. They give them pedagogical directions. However, these interventions are not true. Giving scientific and moral directions is the direct task of scientific committee. The proper implementation of these principles, which are determined by the committee, requires a civil servant office to deal with matters of election of the teachers and choosing principals.

The civil service office will have various units that will engage in primary and secondary education, high school, school of arts and vocational school. These units will arrange the biographies of the teachers, determine the amount of the deceased or resigning teachers each year and the reasons for which they have left their profession. So, it will be understood how many teachers are required to fill vacant positions. On the other hand, it will determine the amount of children who enter the educational age in each region, and how many of them continue their education at schools. It is the officer bureau that directly controls appointment, promotion and dismissals in all education systems.

Educational Publishing Bureau: In the Ministry of Education, there is a definite need for an educational publishing bureau that arranges and manages the publishing works. The Ministry of Education is obliged to perform activities that will satisfy the needs of the knowledge and wisdom of all the people, not only the teachers of the schools. The main activities of this bureau 
are as follows:

1. Translation of the most important works of international pedagogy (Rousseau, Rabeles, Pestalozzi, Herbart... etc.), the newest and most prevalent publications of child psychology and experiential pedagogy.

2. Translation of works consisting of applicable games related to education and ensuring teachers to benefit from these works.

3. How is a museum of school established?

4. How is a children's club or school cooperative organized and managed?

5. How are the spiritual characteristics, physical and spiritual developments of students inspected and followed?

6. How are the parents interested in school and parent-school relations?

7. Enrichment of the contents of the Ministry of Education Magazine containing a lot of valuable information being issued by the Ministry of Education and publishing it regularly every two or three months.

It is obligatory to bring children and young literature to the scene. Creating children and young literature is one of the most important tasks of the publishing office. There is a great need of publications teaching lots of information by entertaining and saving children and young people from a lot of harmful, humiliating and degrading influences. Therefore, books that are read by our children and young people both in school and outside must be chosen from classics of all countries and our country and from the immortal works. The Ministry of Education has to establish a library for children and young people, and should publish the highest and deadliest works of Turkish and world literature in exquisite books.

Journal is a need for children and young people. It is necessary to save them from ordinary humor and illustrated newspapers, to give them the knowledge and art of the century, to introduce the world of ideas and senses, and to taste their civilized pleasures.

In Ministry of Education, there should be a department which should concern school buildings, educational tools, school hygiene, children's clubs and cinemas, public mobile libraries, sports and training centers.

Republic of Turkey Ministry of Education should have a unit which deals with policies of building structure model. Ministry of Education must have a certain building politics. The school buildings to be built after this should be done taking as an example the most modern schools of our century. For this, there is a need for specialists in school architecture. We will be able to satisfy our young and talented architects by sending new European and American schools to learn school architecture and bringing in qualified professionals from Europe and America.

There is a need for a separate commission providing instruments to raise the level of all people:
Provincial Organization of Ministry of Education: In the provincial organization of the Ministry of Education, there is a need to make some substantive reforms. The whole country should be allocated to seven areas of education (Ankara, Istanbul, Izmir, Adana, Sivas, Erzurum and Diyarbekir) taking into account the natural situation and the closeness of economic activities as much as possible: Number of areas could be ten.

Each area will be under the administration of regional director who has great authority and guide supervisors.

Regional managers and guiding supervisors will have all the tools. The main ones are: The last system a printing press - a small training museum (connected to the central museum). It will be very beneficial to arrange an education train including a theater, a club and an automobile, if possible, a three-car, radio telegraph and wireless telephone installation, and cinema machine. In every education region, secondary school, teacher training high school and school of art should meet as a group. That all these schools will be formed in a collective way creates a great school neighborhood, a great solidarity and a family for teachers. The various degrees and types of the schools will be greatly aided by each other in terms of curriculum and instruction.

Laboratory, workshop, library, museum, etc. will not be obliged to do all the installations for each school separately.

The Ministry of Education must make self-government a philosophy, instead of a discipline that slaves to itself in the management mentality.

Likewise, neo-liberal policies now advocate that for quality outcomes, the process of instruction at schools needs highly competent and motivated teachers and principals. To ensure high quality human sources at schools, therefore, it needs accountability mechanisms that devolve the responsibilities at school level, share the authority of decision-making with the parents and teachers, student measurement and evaluations, data-driven decision making, giving parents the right for school choice, teaching staffs' professional competencies and their capacity improvement $[22,23]$.

Similarly, in later reforms in educational administration self-evaluation became an important part of evaluation in Turkish education system as a part of strategic management [24].

\subsection{What Are the Opinions and Recommendations of Sadrettin Celâl Antel about Department of Lifelong Learning and Adult Education?}

In all people's experience after formal education and people who can't benefit from formal education, can obtain as required by information and ability are related to informal education. Thus, the importance of public education in the education system is increased. Public education, which is performed with "adult education", "informal education" and "public education", is expressed 
as a regular and organized educational effort on adults and people who are situated out-of school [25].

According to Sadrettin Jalal's thoughts about the importance of public education, the education issue is a social issue before everything else. Good public education cannot be considered apart from the political and economic system of the country.

The aim of education is to raise the cultural level of the nation from the intentional side of education, to regulate the production of the country and to raise elements that will increase them. Institutions (such as cinema and theatre) that are related to education of young people and public must be got under control.

The children we will educate are not just citizens of a certain state or our state. They may be citizens of other countries. A worker, a fisherman, a farmer as well as a mining engineer, a teacher, a writer is a producer. For this reason, the most important task of the school is to acquire the necessary knowledge, ethics, moral, political opinions and habits in order to become conscious citizens of the Turkish Republic in the new generation.

Opening schools in the form of "farming schools" is also vital in agricultural areas. Citizens should be educated in accordance with the characteristics of the environment in which these people lived.

Teachers' role in public education is great. The teacher will make the people warm and relate to the school. The village and town teachers will "heat up" the masses of the people, if they are to run for their material and spiritual help in the most difficult times of the villagers' confusion in their lives. Then the teachers will really be the teacher of public.

The school will be the center of inspiration for the community life: The school will be a center of inspiration and a source of community life by having open library, playground, sample field and garden, museum, exhibitions, conventions, musicals and radio concerts. The organization of school in this way guides all auspicious enterprise directory held in Turkey and will contribute to progress in the field of public education.

The government has a duty to raise the level of all people. We cannot wait for increase of teacher training school to raise teachers and educate all our children who are in the age of education.

In 1926's Turkey, three-quarters of children in education age do not go to school. They are deprived of all kinds of education and decency. Therefore, these children, young people and illiterate public who cannot benefit from the need for education are required to have non-school instruments to get sufficient education. This issue is, in itself, an important and comprehensive issue. We need to examine and learn from public education organizations of Denmark, USA, and German which are very professional in this field. In addition, we must investigate the ones whose social situations are similar to ours and who have revolved and have taken care of this issue in the most fundamental and practical way.

Just teaching reading and writing are not desired in public education. The aim is to make social, political and economic education. So, the aim is to make the farmers of the most remote villages a conscious citizen of the Republic. For this aim, we try to benefit from public lecture halls, mobile libraries, cinemas and theaters, conferences and all other means.

Likewise, self-learning and lifelong learning were accepted as a vital part of Turkish Education system. In order to ensure this, content and teaching methods have changed [26]. Furthermore, educational sciences department has been reorganized and life-long learning head department has been established in 2017.

\subsection{What Are the Opinions and Recommendations of Sadrettin Celal Antel about Department of Educational Technology?}

In the main point of education, the child's personal observation and examination is today replaced by the book. The work of giving information in our schools is taught as separated courses. However, children are stunned by these events, which do not show a separate existence in nature and community and are often confronted with each other. They do not have the simplest knowledge about the form of object, color, weight of objects, distance and time. They cannot appreciate and estimate any weight, size, and distance and use a simple barometer and thermometer.

Children have difficulty in understanding the emergence of events. Young people who read geography and history for many years in high school have no idea about the faces of the Greek and Roman civilizations, the differences of the Medieval Age and Renaissance, the features of the feudal regime, the development of industry and transportation tools and the life conditions in various periods of civilization.

Unfortunately, the vast majority of the high school graduates and students of Darulfunun were alienated from the geography of the country. For example, student is totally incapable of designing and understanding the geographical, ethnographical, economic, military, artistic and important aspects of the province of Mosul, the prevailing position of petroleum in global economics and politics "if they have read articles on these issues in newspapers and magazines". In this period, they will not be given abstract, historical and moral lessons that they are not understand and need to learn. The objects and trades they see in their surroundings will be examined and the results of these examinations and their personal feelings and desires will be tried to be expressed through mother tongue, painting, hand work, figures and simple sketches.

Handcrafts: it is an important educational tool because children are training their spiritual angels, expressing their 
personalities and developing their creative abilities. When girls sew curtains for their classes, tablecloths for dining tables, socks or undervests for brothers or needy friends and cook; when men decorate the coops for the chickens, the chairs for the classrooms, the tables and the closets, they make valuable asset.

Industry-soil inspection laboratories: In these science laboratories, there will be special tools, equipment and supplies that are essential for them. Activities are performed such as production with new method and new tools, examination of the machines and examination of the properties of the soil in various areas.

In natural examination courses, windmills, farm animals, field flowers and streams should be studied. The student would take notes during all these observations and examinations and will make various pictures and sketches. Then, they would classify them in school and combine them with those of their other friends, so they would systematically construct the conclusions of their observations and examinations. During the hours dedicated to the handcrafts, they would make collections of stones, flowers, and insects; they will model a fruit or animal mud and make a wooden comb and soap, a windmill.

With the help of tables, pictures and historical documents, it will be possible to make comparisons between the state of agriculture, customs and the conditions of life in today and, for example, the situation a hundred years ago.

\subsection{What Are the Opinions and Recommendations of Sadrettin Celâl Antel about Department of Psychological Counseling and Guidance?}

While there were many opinions and suggestions related to guidance in this report which was dated 1926, no proposal concerning the dimension of psychological counseling was found. The reason for this is that at the time of publication of the report, the psychological counseling has not yet had a work or there are very few in the country. Sadrettin Celal Antel's opinions and suggestions related to Department of Guidance and Psychological Counseling are useful in evaluating today's educational and vocational guidance.

A poor child who finishes his first education, of course, is obliged to be put into a life struggled to earn his bread with his own effort at a time when he continues to earn a living because of his life concern, no matter how great a skill, a deep intelligence and a talent. On the other hand, even if it is idle, idiot and lazy, the wealthy child possesses the possibility of ascending to the disposal of Higher education. All the education and training gates are open for him.

Due to the fact that education rights of children depends on their family's wealth instead of their intelligence and ability, their original intelligence and abilities are extinguished before they have the chance to improve. At the same time, after they have finished their education, those who do not have the desire and ability to education gain a status but they are not worthy. Due to the fact that the education is not organized according to their personal abilities and capabilities, not only in our whole life, but even in the most marginalized countries, we are coincident with the bad doctors, incompetent engineers and those who are engaged in high-ranking positions in every field. So, how much financial and moral fortunes are going to be sick, how badly work all the branches of the administration machine.

It is imperative to individualize the education: It is necessary to individualize education as much as possible. It is not right to ask each child to do the same job at the same time, taking into account the spiritual and physical characteristics of young people in terms of intelligence, ability and strength of children. Therefore, it must be a course system instead of a class system. It is necessary to ensure that children and young people do their best to work according to their abilities, to bring their personal and original works, to have something and not to gain something, to bring something to the square and to express their feelings and ideas. The most important deficiency that will not be tolerated in the school is the lack of enthusiasm, negligence and apathy.

This is such a disease: drug the whole life of the school, poison all spirits. The social and moral needs of the youth are neglected. Neglecting social and moral education of young people is one of the greatest faults of our schools. Military system and teaching methods of schools develop primitive feelings such as hodgepodge (egoist-arrogant), jealousy and desire to be alone. Young people who grow up in this way also have a deeply unconcerned tendency towards community affairs. At the same time, these young people deprive themselves of their own ability to undertake and perform their own activities, such as creating original works, attempting to achieve by relying on their own strengths and powers.

\section{Results}

When the historical foundations of educational sciences department in Turkey are analyzed, it is observed that the report is an important work. Although YÖK determined the education branches as 8 categories in 2016, this report has been considered as an important reference source in terms of giving various ideas to the education scholars and to handle the educational sciences in a multi-faceted way.

In today's changing and evolving conditions, the numbers and changes in education branches increase. Although this report was written approximately a century ago, it also includes views and recommendations for the upbringing of the human type needed by 21 st Century education. The evaluation of this report according to the 
conditions of the day can give an idea to determine the purpose of educational sciences branches. In the report, the need to make the best use of education in social development in the light of a social philosophy of education has been emphasized. In terms of science of Education's yesterday, today and tomorrow, this report has a great effect on existing Republic of Turkey Education system.

Today, the Scientific Committee, which has been voiced to report, converted to board of education and discipline, it has been informed that the undersecretary of the Ministry of National Education is still present today, the Publications Department is now serving as the Directorate of Departments, the Inspection Board today is the Inspection Board Presidency, civil servants and statistics bureau today is the Human Resources and Personnel Department. All the developments were affected by the report.

Sadrettin Celal Antel has stated that, for children in the field of measurement and evaluation in education, the application of current exams has a negative effect on the psychological structures of children. It has been stated that the application of the scoring system for assessment and evaluation and this system will be of great benefit in terms of knowledge of children and young people's intelligence, individual and special abilities, psychological characteristics, intelligence levels, health conditions and signs in terms of both students and teachers.

When the course schedules are made, it is emphasized that it is necessary to select course subjects from the surrounding circulating products and economic activities, and to take into account the intelligence, ability, psychological and physical characteristics of the students according to their individual characteristics. The programs should be prepared taking into consideration of the Dalton Plan, Declori, Couzine, John Dewey, Ferreira methods and should be applied especially in the applied schools depending on the teacher training schools.

From the point of view of educational administration, it has been requested that the Ministry of Education receives all rights and becomes a great Ministry of National Education in all its meaning, and it is emphasized that it is wrong to make constant changes with personal thought. Ministry of Education's central and provincial organizations of some of the changes, which are: the association of the inspection work according to scientific principles; establishing education publishing bureau which categorizes and manages the publications, publishes a magazine for children and young people and becomes a particular building structure policy of the Republic of Turkey Ministry of Education; the establishment of a school district; the establishment of a regional directorate and the establishment of a system of guide inspectors, an important task for today's teachers, are emphasized. In terms of management understanding, it is suggested that instead of strict discipline, responsibility and self-management philosophy should be extended.

The main purpose of public education is to raise the cultural level of the nation and to organize the production of the country and to raise the elements that will increase them. It is proposed to set up "Farming Schools" to realize this aim. It is desirable that the role of the teachers in public education is great, so that the village and town teachers are the ones who understand the work, not the word. It is emphasized that public education is not just to teach reading and writing, but the main purpose is to give social, political and economic education. Education has, above all, been viewed as a social issue and it has been stated that good public education cannot be considered separately from the political and economic system of the country.

From the point of view of educational technologies, it has been stated that handcraft lessons are loaded with great duties and that the handicraft lessons must be benefited in the construction of the equipment to be used in education and training. It has been proposed that the course instruments are constructed from the materials obtained from the observation and examination results that exist in nature.

While there were many opinions and suggestions related to guidance in this report which was dated 1926, no proposal concerning the dimension of psychological counseling was found. The reason for this is that at the time of publication of this report, the psychological counseling has not yet had a work or there are very few in the country. Sadrettin Celal Antel's opinions and suggestions related to Department of Guidance and Psychological Counseling are useful in evaluating today's educational and vocational guidance.

The mistakes that have been made about guidance are emphasized and intelligence and ability are mentioned. Particularly in the educational experience of children, it is stated that the riches of the families are more decisive factors than the intelligence and ability. It is pointed out that not directing children according to intelligence and talent is a loss of national wealth.

\section{REFERENCES}

[1] Özoğlu, S. Ç, (1997). Eğitim bilimleri-cumhuriyet döneminde türkiye'de bilim "sosyal bilimler"Ankara: TÜBA Matbaas1: 157-181.

[2] Varış, F. (1988). Eğitim bilimine giriş, Ankara. A.Ü. EBF Yayınları. No: 159.

[3] Özsoy, S. \& Ünal, I. L. (2010). Türkiye'de eğitim bilimleri ve öğretmen yetiştirme: Bir yol ayrımı öyküsü. Eğitim bilimleri felsefesine doğru. Ankara: Tan Kitabevi Yayınları.

[4] Yaylacı, A. F, Gök, E. \& Aydoğan, İ. (2017). Educational sciences and where to find them? A critical analysis of the council of higher education's current structural changes in faculties of education. Mediterranean Journal of Educational 
Research, 11(21): 1-18.

[5] Mala, N. (2011). An evaluation of the primary education curricula in accordance with pragmatism and progressivism from the foundation of turkish republic to today. Yayınlanmamış Doktora Tezi), İnönü Üniversitesi Eğitim Bilimleri Enstitüsü, Malatya.

[6] Karagöz, S \& Duman, T. (2014). 1908-1928 yıları aras1 süreli yayınlarda yer alan eğitim görüşleri ve öneriler. Uluslararası Sosyal Araştırmalar Dergisi, 7 (35): 576-594.

[7] Karagöz, S. (2014). Educational views on periodicals starting with the second constitutionalist period to alphabet reform and their reflection to republic education (1908-1928) (Yayınlanmamış Doktora Tezi). Gazi Üniversitesi Eğitim Bilimleri Enstitüsü, Ankara.

[8] Yüksel, S. (2011). Türk üniversitelerinde eğitim fakülteleri ve öğretmen yetiştirme. 2. Baskı. Ankara. Pegem Akademi Yayınları

[9] Antel, S. C (1926), Maarif teşkilatı hakkında bir layiha. Maarif için on senelik inkişaf programı, Maarif Vekâleti Mecmuas1 7:135-246.

[10] Baltacıoğlu, İ. H. (1998). Hayatım, İstanbul: Dünya Yayınları.

[11] Ülken H. Z (1966). Türkiye'de Çağdaş Düşünce Tarihi. 8. Baskı. İstanbul. Ülken Yayınları.

[12] Şemin, R. (1987). Sadrettin Celâl Antel, cumhuriyet dönemi eğitimcileri. Ankara: UNESCO Türkiye Milli Komisyonu Yayın1.

[13] Siyavuşgil, E. S. (1954). Profesör Sadrettin Celâl Antel. Pedagoji bülteni I, İstanbul: İstanbul Üniversitesi Edebiyat Fakültesi Yayını.

[14] Berkol, B. (2000). 44'üncü ilkokul. M. Ü. Atatürk Eğitim Fakültesi Eğitim Bilimleri Dergisi, 12: 53-58.

[15] Merriam, S. B. (2001). Qualitative research and case study applications in education. San Francisco: Jossey Bass.
[16] Yıldırım, A. \& SSimşek, H. (2005). Sosyal bilimlerde nitel araştırma yöntemleri. Ankara: Seçkin Yayınevi

[17] Ata, B. (2014). A Turkish Intellectual between Marxist Politics and Durkheim's Pedagogy: Sadrettin Celâl Antel and History Teaching. Education and Science, 39(175): $27-40$.

[18] Cakmak, Ö. (2008). The influence of education on economy and development. D.Ü. Ziya Gökalp Eğitim Fakültesi Dergisi, 11, 33-41.

[19] Sönmez, V. (2012). Eğitim Felsefesi. Anı Yayıncılık: Ankara.

[20] Özçelik, D.Ali (2013). Okullarda Ölçme ve Değerlendirme. Pegem Akademi Yayıncılık. 2. Baskı. Ankara.

[21] Dilekli, Y \& Karagöz, S. (2018). İhsan Sungu' nun Program Değerlendirme Modelinin Avrupa ve Amerika'da Yaygın Kullanılan Program Değerlendirme Modelleri ile Karşılaştırılması. OPUS Uluslararası Toplum Araştırmaları Dergisi, 8 (14): 465-496. DOI: 10.26466/opus.391195

[22] Erdağ, C. (2017). Accountability Policies at Schools: A Study of Path Analysis. Educational Sciences: Theory Practice, 17(4): 1405-1432.

[23] Erdağ C. \& Karadağ E. (2017). School Accountability Models: A Holistic Review. Turkish Journal of Business Ethics, 10(2), 303-341., Doi: 10.12711/tjbe.2017.10.2.0004.

[24] Yenipınar, Ş., Akgün, N. (2017). Stratejik Yönetimin İlköğretim Kurumlarında Uygulanması. Abant İzzet Baysal Üniversitesi Eğitim Fakültesi Dergisi, 17 (2): 1039-1060.

[25] Türkoğlu, A. \& Uça, S. (2011). Public education in turkey: historical development, problems and solutions to these problems. Adnan Menderes Üniversitesi Eğitim Fakültesi. Eğitim Bilimleri Dergisi, 2 (2): 48-62.

[26] Dilekli, Y. \& Tezci, E. (2016). The relationship among teachers' classroom practices for teaching thinking skills, teachers' self-efficacy towards teaching thinking skills and teachers' teaching styles, Thinking Skills and Creativity, 21, 144-151. 